\title{
PENERAPAN METODE SIMPLE ADDITIVE WEIGHTING PADA SISTEM PENDUKUNG KEPUTUSAN UNTUK MENENTUKAN KENAIKAN GAJI KARYAWAN
}

\author{
Nasrun Marpaung \\ Sistem Informasi, STMIK Royal \\ email: nasrunavara@gmail.com
}

\begin{abstract}
A determination of employee salary raise has a lot of obstacles to employee appraisal so the results obtained don't match the specified criteria. The use of technology in a decision support system is capable of providing solutions to help the manager who makes decisions. The decision support system which was designed to help determine the salary raise for the employees of AKBID As-Syifa Kisaran utilizes FMADM (Fuzzy Multiple Attribute Decision Making) with one of its methods, namely SAW (Simple Additive Weighting) which produces the best alternative decision of several alternatives in which the best alternative is obtained through a weighted sum from performance rating on every alternative. This method was chosen because it is able to choose the best alternative based on the criteria which have been calculated with the weight value of each attribute. The best alternative decision obtained was 2 employees or $14 \%$ of 14 employee data which have been processed.
\end{abstract}

Keywords: Decision Support System, Simple Additive Weighting, Employee Salary Raise

\begin{abstract}
Abstrak: Penentuan kenaikan gaji karyawan pada sebuah instansi maupun perusahaan banyak terdapat kendala terhadap penilaian karyawan sehingga hasil keputusan yang diperoleh tidak sesuai kriteria yang ditentukan. Pemanfaatan teknologi pada sebuah sistem pendukung keputusan mampu memberikan solusi untuk membantu manajer pengambil keputusan. Sistem pendukung keputusan yang dibuat untuk membantu menentukan kenaikan gaji karyawan AKBID As-Syifa Kisaran memanfaatkan FMADM (Fuzzy Multiple Atribute Decission Making) dengan salah satu metodenya yaitu SAW (Simple Additive Weighting) yang menghasilkan alternatif keputusan terbaik dari beberapa alternatif. Dimana alternatif terbaik diperoleh melalui penjumlahan terbobot dari rating kinerja pada setiap alternatif. Metode ini dipilih karena mampu memilih alternatif terbaik berdasarkan kriteria yang sudah dihitung dengan nilai bobot dari setiap atributnya. Alternatif keputusan terbaik diperoleh sebanyak 2 karyawan atau 14\% dari 14 data karyawan yang telah diolah.
\end{abstract}

Kata Kunci : $\quad$ Sistem Pendukung Keputusan, Simple Additive Weighting, Kenaikan Gaji Karyawan. 


\section{PENDAHULUAN}

Pemanfaatan perkembangan teknologi saat ini tidak lagi pada bidang tertentu saja, perkembangan yang begitu pesat berpengaruh pada kemudahan semua aktifitas yang sulit untuk dilakukan manusia dapat dikerjakan dengan mudan, efektif dan efisien. Dengan peranan teknologi bidang komputasi tentunya sangat memberikan peluang untuk menyelesaikan permasalahan yang kompleks.

Sistem pendukung keputusan adalah suatu sistem informasi spesifik yang ditujukan untuk membantu manajemen dalam mengambil keputusan yang berkaitan dengan persoalan yang bersifat semi terstruktur. Sistem ini memiliki fasilitas untuk menghasilkan berbagai alternatif yang secara interaktif digunakan oleh pemakai. Kata kunci lainnya adalah penggunaan model sebagai dasar pengembangan alternatif dan pemanfaatan komputer. Dapat disimpulkan bahwa tujuan sistem pendukung keputusan dapat memberikan kemudahan efektifitas dan efisiensi suatu pekerjaan setiap manejer dalam melakukan setiap pengambilan keputusan. (Niswatin, 2015).

$$
\text { Penerapan Sistem Pendukung }
$$

Keputusan dengan metode Simple Additive Weighting (SAW) digunakan dalam penentuan kenaikan gaji karyawan. Dalam menentukan proses penetapan kenaikan gaji karyawan di perusahaan banyak terdapat kendala-kendala atau masalah yang harus dihadapi perusahaan antara lain efisiensi waktu, banyak perbandingan variabel yang diuji, pengambilan keputusan apakah karyawan tersebut berhak naik gajinya atau tidak dan banyaknya berkas data karyawan yang diolah. Selama ini, penentuan karyawan yang termasuk dalam kriteria kenaikan gaji di AKBID As-Syifa Kisaran belum menggunakan suatu sistem sehingga hasil yang diperoleh kurang begitu akurat, pemilihan dilakukan secara acak dan hanya berdasarkan pendidikan terakhir. Oleh sebab itu, untuk mendapatkan karyawan yang memenuhi kriteria yang tepat maka dalam penelitian ini penulis harus menentukan kriteria-kriterianya terlebih dahulu. Setiap kriteria ini memiliki bobot masing-masing yang nantinya diolah dengan metode Simple Additive Weighting (SAW) sehingga didapatkan hasil dalam penentuan kenaikan gaji karyawan.

$$
\text { Metode Simple Additive }
$$

Weighting (SAW) yang juga dikenal sebagai kombinasi bobot linear atau metode scoring adalah teknik keputusan yang sederhana dan multi atribut yang paling banyak digunakan. Metode ini didasarkan pada bobot rata-rata. Skor evaluasi dihitung untuk setiap alternatif dengan mengalikan nilai skala yang diberikan kepada alternatif yang atribut dengan bobot kepentingan relatif ditetapkan langsung oleh pengambil keputusan yang diikuti dengan menjumlahkan hasil untuk semua kriteria, (Alireza Afshari et al, 2010).

\section{METODOLOGI}

\section{Studi Literatur}

Studi literatur adalah tahap melakukan pembelajaran mengenai sistem pengambil keputusan menggunakan metode Simple Additive Weighting (SAW). Data yang diolah berasal dari buku-buku dan jurnal yang berkaitan dengan konsep Sistem Pendukung Keputusan menggunakan metode Simple Additive Weighting (SAW).

Studi lapangan di lakukan pada Kampus AKBID As-Syifa Kisaran. Adapun data-data yang diperlukan dalam pengolahan data sistem pendukung keputusan dengan metode SAW yaitu: Data karyawan yang diperlukan untuk diolah dan diterapkan pada sistem pendukung keputusan dengan metode 
SAW. Data-data karyawan yang dijadikan sebagai data kriteria, data himpunan kriteria, data alternatif, data klasifikasi .

\section{Analisa Sistem}

Analisa dilakukan untuk
mendapatkan suatu hasil sebagai pendukung keputusan untuk menentukan kenaikan gaji karyawan berdasarkan metode penelitian yang dilakukan. Data-data yang diperoleh dari metode penelitian yang dilakukan kemudian akan dianalisis sehingga diperoleh beberapa kriteria sebagai input dengan nilai yang sudah ditentukan yang nantinya akan dikalkulasikan dengan rumus sistem pendukung keputusan metode Simple Additive Weighting.

Langkah penyelesaian metode FMADM dengan metode SAW antara lain:

a. Memberikan nilai setiap alternatif (Ai) pada setiap kriteria $(\mathrm{Cj})$ yang sudah ditentukan.

b. Memberikan nilai bobot (W) yang juga didapatkan berdasarkan nilai crisp.

c. Melakukan normalisasi.

d. Melakukan proses perankingan dengan cara mengalikan natriks ternormalisasi

e. Menentukan nilai preferensi untuk setiap alternatif (Vi)

\section{Penerapan Metode SAW untuk Pengolahan Data}

Pada tahap pengolahan data, data yang diolah dengan metode Simple Additive Weighting, terlebih dahulu dilakukan penentuan alternatif, sesuai dengan tujuan dari sistem pendukung keputusan penentuan kenaikan gaji karyawan, kemudian menentukan kriteria dan himpunan kriteria tiap-tiap alternatif yang akan dihitung dengan memasukkan nilai bobot pada tiap-tiap kriteria, sehingga memperoleh nilai akhir dengan bentuk nilai normalisasi dan preferensi sehingga memperoleh nilai akhir sebagai solusi untuk menentukan kenaikan gaji karyawan pada AKBID As Syifa Kisaran.

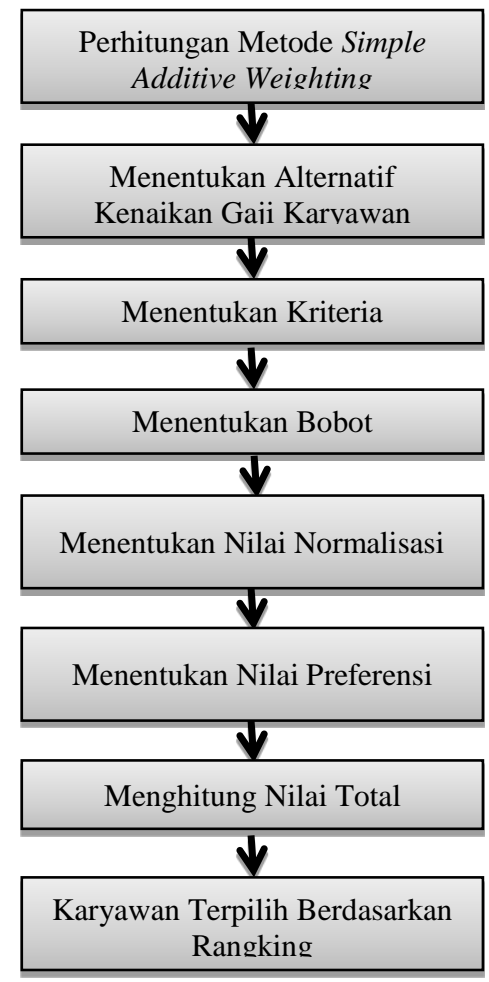

Gambar 1. Pengolahan Data Metode SAW

\section{Perhitungan Data Kriteria}

Kriteria yang dibutuhkan dalam menentukan kenaikan gaji karyawan pada penelitian ini meliputi:

a. Kriteria Kedisiplinan

Data pada kriteria kedisiplinan ini diambil dari absensi karyawan yang sudah dikalkulasikan dan direkap persentase kehadirannya, di mana jumlah data kedisiplinan yang dihitung adalah jumlah kehadiran dalam 1 (satu) tahun, yang mana nilai persentase perbulannya dirata-ratakan. Pada kriteria kedisiplinan terdapat 4 variabel dan untuk $95.000 \%-96.250 \%$ dianggap variabel ke 0 , sehingga dengan menerapkan rumus terbentuk nilai begitu selanjutnya untuk menentukan nilai pada variabel yang 
lainnya. Untuk lebih jelas dapat dilihat pada tabel 1 berikut:

Tabel 1. Jangkauan Nilai Fuzzy Terhadap Kedisiplinan Karyawan

\begin{tabular}{|c|c|c|}
\hline $\begin{array}{c}\text { Kriteria } \\
\text { Kedisiplinan } \\
\left(\mathrm{C}_{1}\right)\end{array}$ & $\begin{array}{l}\text { Nilai } \\
\text { Fuzzy }\end{array}$ & Keterangan \\
\hline $\begin{array}{c}95.000 \% \text { - } \\
96.250 \%\end{array}$ & 0 & $\begin{array}{c}\text { Kurang } \\
\text { Disiplin } \\
\text { (KD) }\end{array}$ \\
\hline $\begin{array}{l}96.251 \% \text { - } \\
97.500 \%\end{array}$ & 0,333 & $\begin{array}{l}\text { Cukup } \\
\text { Disiplin } \\
\text { (CD) }\end{array}$ \\
\hline $\begin{array}{c}97.501 \% \text { - } \\
98.750 \%\end{array}$ & 0,667 & Disiplin (D) \\
\hline $\begin{array}{l}98.751 \%- \\
100.000 \%\end{array}$ & 1 & $\begin{array}{c}\text { Sangat } \\
\text { Disiplin } \\
\text { (SD) }\end{array}$ \\
\hline
\end{tabular}

\section{Kriteria Masa Kerja}

Data pada kriteria masa kerja ini diambil dari rekap data karyawan pada kategori lama bekerja karyawan di AKBID As Syifa. Dari data tersebut ditentukan nilai range. Nilai range yang sudah ditentukan selanjutnya akan diintegrasikan ke bilangan fuzzy seperti pada tabel 4.5 berikut ini:

Tabel 2. Jangkauan Nilai Fuzzy Terhadap Masa Kerja Karyawan

\begin{tabular}{ccc}
\hline $\begin{array}{c}\text { Kriteria Masa } \\
\text { Kerja }\left(\mathrm{C}_{2}\right)\end{array}$ & $\begin{array}{c}\text { Nilai } \\
\text { Fuzzy }\end{array}$ & Keterangan \\
\hline $\begin{array}{c}0-2.000 \\
\text { tahun }\end{array}$ & 0 & $\begin{array}{c}\text { Tidak Lama } \\
(\mathrm{TL})\end{array}$ \\
\hline $\begin{array}{c}2.001-4.000 \\
\text { tahun }\end{array}$ & 0,25 & $\begin{array}{c}\text { Kurang } \\
\text { Lama (KL) }\end{array}$ \\
\hline $\begin{array}{c}4.001-6.499 \\
\text { tahun }\end{array}$ & 0,5 & $\begin{array}{c}\text { Cukup Lama } \\
\text { (CL) }\end{array}$ \\
\hline $\begin{array}{c}6.500-8.999 \\
\text { tahun }\end{array}$ & 0,75 & Lama (L) \\
\hline $\begin{array}{c}>=9.000 \\
\text { tahun }\end{array}$ & 1 & $\begin{array}{c}\text { Sangat Lama } \\
\text { (SL) }\end{array}$ \\
\hline
\end{tabular}

b. Kriteria Pendidikan Terakhir

Data pada kriteria ini diambil dari rekap data karyawan pada kategori pendidikan terakhir karyawan. Pendidikan terakhir memiliki 5 jangkauan nilai yang selanjutnya akan diintegrasikan ke bilangan fuzzy seperti pada tabel 4.6 berikut ini:

Tabel 3. Jangkauan Nilai Fuzzy Terhadap Pendidikan Terakhir

\begin{tabular}{ccc}
\hline $\begin{array}{c}\text { Kriteria } \\
\text { Pendidikan } \\
\text { Terakhir }\left(\mathrm{C}_{3}\right)\end{array}$ & $\begin{array}{c}\text { Nilai } \\
\text { Fuzzy }\end{array}$ & Keterangan \\
\hline SMA sederajat & 0 & $\begin{array}{c}\text { Sangat } \\
\text { Rendah } \\
(\mathrm{SR})\end{array}$ \\
\hline D-III & 0,25 & Rendah (R) \\
\hline D-IV & 0,5 & Sedang (S) \\
\hline S1 & 0,75 & Tinggi (T) \\
\hline S2 & 1 & $\begin{array}{c}\text { Sangat } \\
\text { Tinggi (ST) }\end{array}$ \\
\hline
\end{tabular}

c. Kriteria Keahlian Kerja

Data pada kriteria ini diambil dari jumlah pelatihan yang pernah diikuti oleh karyawan. Keahlian kerja memiliki 5 jangkauan nilai yang selanjutnya akan diintegrasikan ke bilangan fuzzy seperti pada tabel 4.7 berikut ini:

Tabel 4. Jangkauan Nilai Fuzzy Terhadap Keahlian Kerja

\begin{tabular}{ccc}
\hline $\begin{array}{c}\text { Kriteria } \\
\text { Keahlian } \\
\text { Kerja } \\
\left(\mathrm{C}_{4}\right)\end{array}$ & $\begin{array}{c}\text { Nilai } \\
\text { Fuzzy }\end{array}$ & Keterangan \\
\hline Od & 0 & $\begin{array}{c}\text { Sangat } \\
\text { Rendah (SR) }\end{array}$ \\
\hline 1 & 0,25 & Rendah (R) \\
\hline 2 & 0,5 & Sedang (S) \\
\hline 3 & 0,75 & Tinggi (T) \\
\hline 3 & 1 & $\begin{array}{c}\text { Sangat } \\
\text { Tinggi (ST) }\end{array}$ \\
\hline
\end{tabular}

d. Kriteria Status Pernikahan

Data pada kriteria ini diambil dari status pernikahan karyawan. Status pernikahan memiliki 2 jangkauan 
nilai yang selanjutnya akan diintegrasikan ke bilangan fuzzy seperti pada tabel 4.8 berikut ini:

Tabel 5. Jangkauan Nilai Fuzzy Terhadap Status Pernikahan

\begin{tabular}{ccc}
\hline $\begin{array}{c}\text { Kriteria } \\
\text { Status } \\
\begin{array}{c}\text { Pernikahan } \\
\left(\mathrm{C}_{5}\right)\end{array}\end{array}$ & $\begin{array}{c}\text { Nilai } \\
\text { Fuzzy }\end{array}$ & Keterangan \\
\hline $\begin{array}{c}\text { Belum } \\
\text { Menikah }\end{array}$ & 0,5 & $\begin{array}{c}\text { Belum } \\
\text { Menikah } \\
(\mathrm{BM})\end{array}$ \\
\hline Menikah & 1 & Menikah $(\mathrm{M})$ \\
\hline
\end{tabular}

\section{Pengujian Sistem pada Aplikasi}

Pada tahap ini menyiapkan data untuk diolah menggunakan metode Simple Additive Weighting. Data mentah yang diperoleh disusun sesuai dengan kriteria yang sudah dihitung dan memperoleh nilai akhir kemudian data ditetapkan menjadi sebuah data input yang siap diuji dengan aplikasi Simple Additive Weighting.

\section{Evaluasi Hasil}

Tahap evaluasi hasil ini melakukan proses data dari AKBID As-Syifa Kisaran sebagai input, lalu menggunakan metode Simple Additive Weighting, menghasilkan beberapa kriteria yang diinginkan. Kesimpulan terhadap hasil menguji dan mengevaluasi dari sistem pendukung keputusan dengan metode Simple Additive Weighting untuk menentukan kenaikan gaji karyawan.

\section{HASIL DAN PEMBAHASAN}

Setelah selesai melakukan analisa terhadap data karyawan maka dirancanglah sebuah sistem yang akan mengolah data tersebut. Setelah sistem selesai dibangun lalu dilakukan implementasi terhadap hasil analisa. Selanjutnya sistem akan diuji apakah sudah berjalan seperti yang sudah dirancang dengan menggunakan metode yang telah ditetapkan. Pengujian juga dilakukan untuk menemukan kekurangan maupun kesalahan yang akan diperbaiki untuk implementasi sistem yang lebih baik.

Hasil yang diperoleh merupakan penerapkan dari metode Simple Additive Weighting (SAW) dengan menentukan kriteria-kriteria beserta bobot yang dijadikan inputan ke dalam sistem. Selanjutnya nilai bobot dari masing-masing kriteria akan dinormalisasi untuk kemudian dikalikan dengan nilai bobot yang telah ditentukan sehingga diperoleh nilai preferensi. Penjumlahan dari nilai preferensi akan menghasilkan ranking dari masing-masing alternatif sehingga diperoleh karyawan yang akan terpilih untuk mendapatkan kenaikan gaji.

Pengolahan data diproses melalui aplikasi/ sistem yang sudah dibuat. Adapun antarmuka dalam sistem dapat digambarkan sebagai berikut:

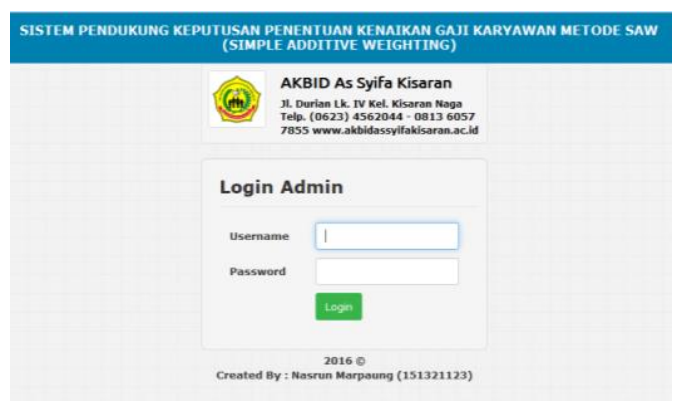

Gambar 1. Tampilan Menu Login Admin

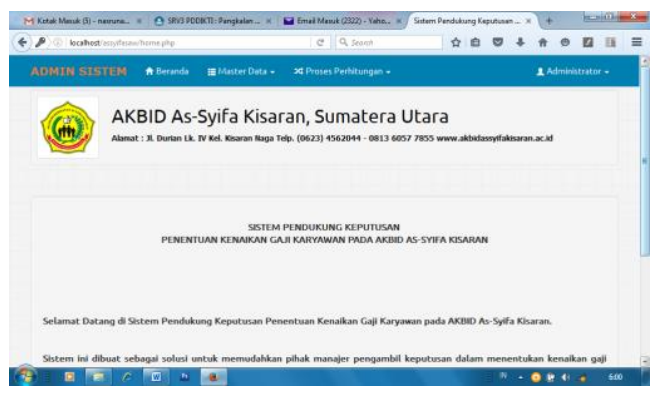

Gambar 2. Tampilan Menu Home 


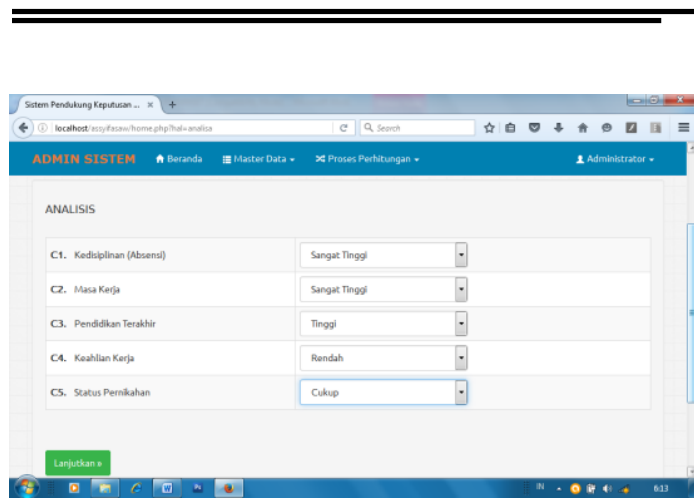

Gambar 3. Form Proses SAW

Gambar 3. Merupakan Form untuk memproses analisis data. Pengujian terhadap form proses SAW dilakukan dengan mengecek hasil ketika tombol lanjutkan diklik dan data yang muncul ketika form pertama kali dijalankan berupa data awal yang diperoleh dari data himpunan kriteria seperti pada gambar 4.

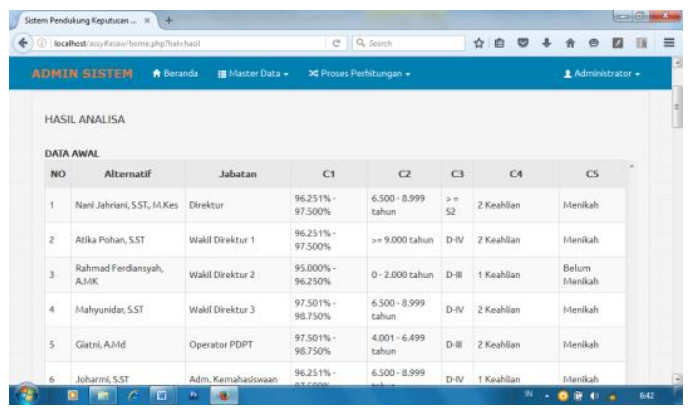

Gambar 5. Data Awal dari Hasil Analisa

Selanjutnya bersamaan dengan proses pertama, normalisasi data juga ditampilkan dibawah data awal.

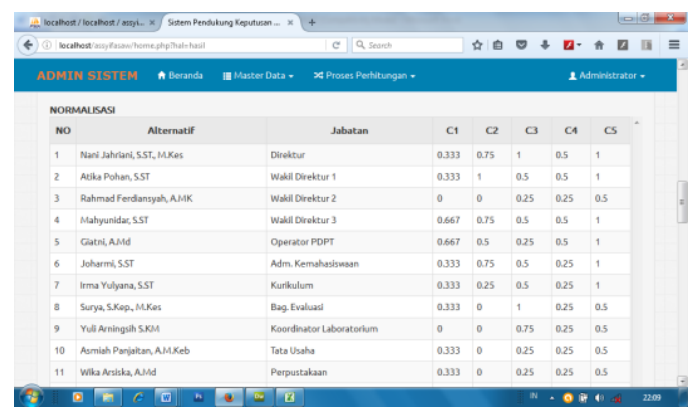

Gambar 6.Normalisasi dari Hasil Analisa

Dari normalisasi data diperoleh data preferensi yang sudah diproses diawal yang juga bersamaan dengan data awal dan data normalisasi.

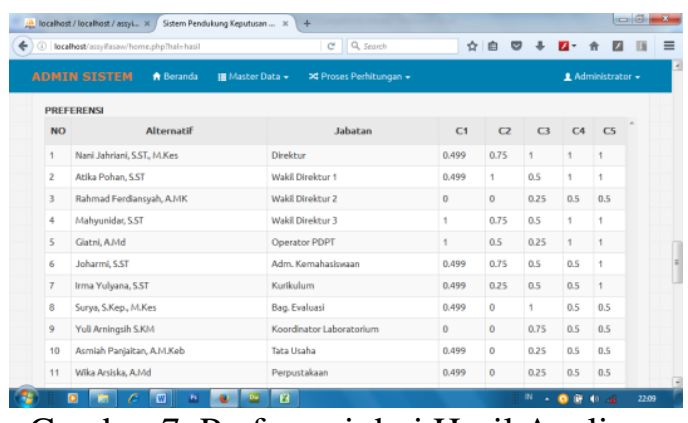

Gambar 7. Preferensi dari Hasil Analisa

Dari nilai preferensi akan muncul ranking sebagai hasil akhir perhitungan dari masing-masing alternatif.

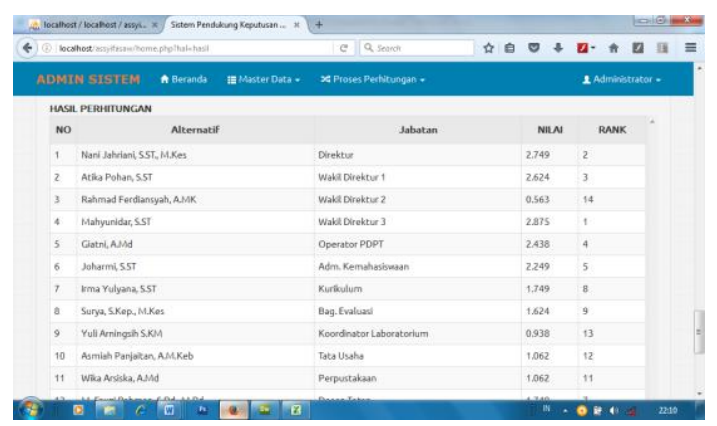

Gambar 8. Hasil Perhitungan dari Hasil Analisa

Kemudian keputusan dari alternatif dengan ranking tertinggi akan muncul sebagai berpotensi naik atau tidak berpotensi untuk ranking dibawah rata-rata. Jika tombol lanjutkan berfungsi dengan baik dan semua angka muncul pada tampilan data dengan tepat maka pengujian terhadap form proses SAW berhasil dilakukan.

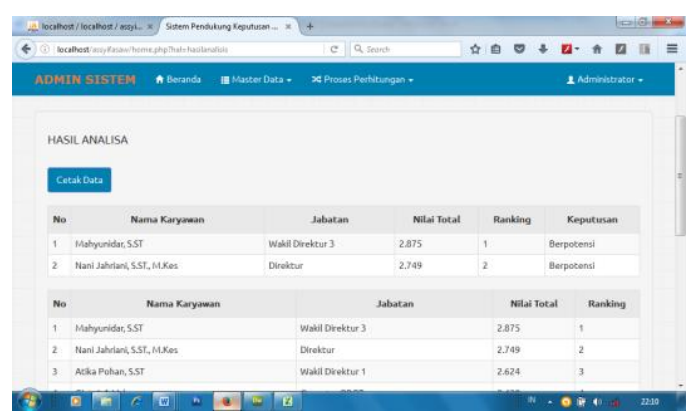


Available online at http://jurnal.stmikroyal.ac.id/index.php/jurteksi

Gambar 9. Hasil Analisa Akhir dengan Tabel Keputusan

\section{SIMPULAN}

Berdasarkan penelitian yang penulis lakukan dan proses analisa hingga menghasilkan suatu data sebagai solusi alternative keputusan dalam penentuan kenaikan gaji karyawan pada AKBID As-Syifa Kisaran menggunakan metode Simple Additive Weighting (SAW), maka dapat diambil kesimpulan sebagai berikut :

1. Dengan melakukan wawancara, observasi, dan pengumpulan data pada AKBID As-Syifa Kisaran, maka dapat ditentukan kriteria-kriteria untuk menentukan kenaikan gaji karyawanr, yaitu Kedisiplinan (Absensi Kehadiran), Masa Kerja, Pendidikan Terakhir, Keahlian Kerja, dan Status Pernikahan.

2. Dengan menerapkan metode Simple Additive Weighting (SAW) pada sistem. Sistem melakukan perhitungan normalisasi dari masing-masing bobot, kemudian dikalikan dengan nilai bobot $(W)$ yang sudah ditentukan untuk mendapatkan nilai preferensi masing-masing kriteria. Selanjutnya didapatlah nilai ranking dari alternatif dengan menjumlahkan nilai preferensi. Nilai ranking inilah

\section{DAFTAR PUSTAKA}

Alireza Afshari, Majid Mojahed and Rosnah Mohd Yusuff (2010). Simple Additve Weighting approach to Personnel Selection Problem. International Journal of Innovation, Management and yang menentukan alternative karyawan yang berpotensi dalam kenaikan gaji. Maka berdasarkan hasil keputusan dengan metode SAW dapat dilihat bahwa alternatif yang terpilih diambil berdasarkan nilai total dengan range $>2,750$. Maka dapat disimpulkan bahwa jumlah alternatif yang terpilih berjumlah 3 orang atau $21,43 \%$ dari 14 data karyawan yang telah diolah.

3. Aplikasi Sistem Pendukung Keputusan menggunakan metode Simple Additive Weighting (SAW) dibangun dengan bahasa pemrograman PHP dan MySQL sebagai database untuk penyimpanan data. Aplikasi terdiri dari beberapa proses, pada masing-masing data. Data alternatif terdiri dari proses input, update, delete, dan tampil data. Data kriteria terdiri dari proses input, update, delete, dan tampil data. Data himpunan kriteria terdiri dari proses input, update, dan tampil data untuk menentukan nilai pada masing-masing kriteria. Data Klasifikasi terdiri dari proses input, update dan tampil data untuk menentukan kriteria-kriteri yang sudah diberi nilai pada himpunan kriteria kedalam data alternatife untuk dilakukan proses penghitungan oleh sistem.

Technology. Vol.1, No 5, Desember 2010. ISSN 2010-0248

Amir Sarifudin et al. (2013). Pembangunan Sistem Informasi Penggajian pada Sekolah Dasar Negeri (SDN) Pacitan. Indonesian Journal on 
Available online at http://jurnal.stmikroyal.ac.id/index.php/jurteksi

Networking and Security. November 2013

Asep Abdul Wahid et al. (2012). Sistem pendukung Keputusan Penentuan Jumlah Pemesanan Barang. Jurnal Algoritma Sekolah Tinggi Teknologi Garut Garut, 9(2): 2302-7339

Asefeh Asemi (2011). The Role of Management Information System (MIS) and Decision Support System (DSS) for Manager's Decision Making Process. International Journal of Business and Management. 6(7)

Dian Novita Handayani et al. (2014). Sistem Pendukung Keputusan Untuk Pemilihan Jurusan Menggunakan Fuzzy Multiple Atribute Decision Making dengan Metode Simple Additive Weighting Studi Kasus Pada SMA Islam Sultan Agung 1. Jurnal Transformatika, 11(2)

Dyah Pratiwi, Juliana Putri Lestari (2014). Decision Support System to Majoring High School Student Using Simple Additive Weighting Method. International Journal of Computer Trends and Technology (IJCTT). 10(3)

E. Manokaran et al. (2011). Application of Multi Criteria Decision Making Tools and Validation with Optimization Technique-Case Study using TOPSIS, ANN \& SAW. International Journal of Management Business Studies. India, 1(3)

Novi Safriadi (2012). Rancang Bangun Sistem Informasi Administrasi Informatika. Jurnal ELKHA, 4(2)

Hilyah Magdalena (2012). Sistem Pendukung Keputusan
Menentukan Mahasiswa Terbaik di Perguruan Tinggi (Studi Kasus STMIK ATMA LUHUR PANGKAL PINANG). Seminar Nasional Teknologi Informasi dan Komunikasi 2012 (SENTIKA 2012) Yogyakarta, 10 Maret 2012.

Husni Faqih (2014). Implementasi DSS Dengan Metode SAW untuk Menentukan Prioritas Pekerjaan Operasi dan Pemeliharaan Sistem Irigasi DPU Kabupaten Tegal. Bianglala Informatika. 2(1)

Muhammad Akbar dan Dafid (2015). Perancangan Sistem Pendukung Keputusan Verifikasi Kelayakan Calon Tenaga Kerja Indonesia (CTKI) dengan Metode Simple Additive Weighting (SAW). Jatisi. 2(1)

Pratiwi et al. (2014). Sistem Pendukung Keputusan Penjuruan Siswa dengan Metode Simple Additive Weighting (SAW). Jurnal Ilmiah SINUS.

Sri Eniyati (2011). Perancangan Sistem Pendukung Pengambilan Keputusan untuk Penerimaan Beasiswa dengan Metode SAW (Simple Additive Weighting). Jurnal Teknologi Informasi DINAMIK. 16(2)

Syamsul (2012). Rancang Bangun Sistem Pendukung Keputusan Pembagian Beban Kerja Dosen (BKD) Berbasis Logika Fuzzy. Jurnal Litek. 9(2)

Tutin Sumanti (2013). Sistem Pendukung Keputusan Pemilihan Mobil Bekas Dengan Menggunakan Metode Simple Additive Weighting (SAW). Pelita Informatika Budi Darma. 5(3) 